\begin{tabular}{|c|c}
\hline $\begin{array}{c}\text { Jurnal Pengabdian Kesehatan Komunitas } \\
\text { (Journal of Community Health Service) }\end{array}$ \\
\hline \\
\hline
\end{tabular}

\title{
EVALUASI SISTEM PELAKSANAAN MANAJEMEN PEMELIHARAAN ALAT MEDIS DI INSTALASI PEMELIHARAAN DAN PERBAIKAN PERALATAN MEDIS RUMAH SAKIT (IP3MRS) RSUD ARIFIN ACHMAD PROVINSI RIAU TAHUN 2020
}

\begin{tabular}{|c|c|}
\hline \multicolumn{2}{|c|}{$\begin{array}{c}{ }^{5} \text { Rumah Sakit Umum Daerah Arifin Achmad Pekanbaru Riau } \\
\text { E-mail: istianaauliani@gmail.com }{ }^{1}\end{array}$} \\
\hline Histori artikel & Abstrak \\
\hline $\begin{array}{l}\text { Received: } \\
\text { 05-11-2020 } \\
\\
\text { Accepted: } \\
\text { 25-05-2021 } \\
\text { Published: } \\
\text { 26-05-2021 }\end{array}$ & $\begin{array}{l}\text { Latar Belakang: Instalasi Pemeliharaan dan pebaikan peralatan } \\
\text { medis rumah sakit (IP3MRS) salah satu Instalasi di RSUD Arifin } \\
\text { Achmad Provinsi Riau berkegiatan menunjang pelayanan } \\
\text { Kesehatan dan bertanggung jawab terhadap peralatan medis. } \\
\text { Tujuan: Mengevaluasi sistem pelaksanaan Manajemen } \\
\text { Pemeliharaan dan pebaikan peralatan medis rumah sakit di RSUD } \\
\text { Arifin Achmad Provinsi Riau. } \\
\text { Metode: Penelitian kualitatif dengan pendekatan deskriptif. } \\
\text { Pengambilan sampel dengan metode purposive sampling. Jumlah } \\
\text { informan terdiri dari informan pangkal Kepala dan staf, fasilitas } \\
\text { pelayanan Medik, informan Kunci Kepala keuangan. } \\
\text { Hasil: Jumlah (SDM) belum sesuai dengan Permenkes, besaran } \\
\text { dana dialokasikan untuk kegiatan harian pemeliharaan alat medis } \\
\text { cukup, bahan baku disediakan belum sepenuhnya terpenuhi } \\
\text { kebutuhan, peralatan dan fasilitas pengadaan alat medis belum } \\
\text { memadai, kebijakan terkait pemeliharaan alat medis sudah } \\
\text { disosialisasikan dengan baik, pelaksanaan perencanaan kegiatan } \\
\text { pemeliharaan alat medis dilaksanakan pada setiap tahunnya, } \\
\text { struktur organisasi dan pembagian kerja tidak memiliki hambata, } \\
\text { pelaksanaan yang dijalankan merujuk kepada program serta } \\
\text { standar operasional (SPO),pengawasan kegiatan pemeliharaan } \\
\text { alat medis meliputi pemeriksaan laporan kegiatan pemeliharaan, } \\
\text { sistem evaluasi pemeliharaan sudah berjalan dengan baik. } \\
\text { Simpulan: Secara umum Sistem Pelaksanaan Manajemen } \\
\text { Pemeliharaan Alat Medis di (IP3MRS) RSUD Arifin Achmad } \\
\text { Provinsi Riau yang dilihat dari tujuan peneliti, terkait SDM, } \\
\text { Ketersediaan Dana, Ketersediaan Peralatan dan Fasilitas, Suku } \\
\text { Cadang, Kebijakan Pemeliharaan, Perencanaan, } \\
\text { Pengorganisasian, Pengawasan, Dan Evaluasi ada beberapa yang } \\
\text { belum optimal } \\
\text { Saran: Disarankan dapat menambahkan SDM guna mengantisipasi } \\
\text { resiko beban kerja, pembelian suku cadang baru yang dibutuhkan }\end{array}$ \\
\hline
\end{tabular}


agar alat yang rusak lebih cepat ditangani, fasilitas Gedung IP3MRS dan gudang penyimpanan suku cadang agar dapat dipisah sehingga staf dapat bekerja dengan baik.

Kata Kunci: Alat Medis, IP3MRS, Manajemen POACE

Background: Installation for maintenance and repair of hospital medical equipment (IP3MRS), one of the installations at Arifin Achmad Hospital, Riau Province, has activities to support health services and is responsible for medical equipment.

Objective: To evaluate the implementation system for the Maintenance Management and repair of hospital medical equipment at Arifin Achmad Hospital, Riau Province.

Methods: Qualitative research with a descriptive approach. Sampling was using purposive sampling method. The number of informants consisted of chief informants and staff, medical service facilities, key informants to the head of finance.

Result: The amount (HR) is not in accordance with the Permenkes, the amount of funds allocated for daily maintenance of medical devices is sufficient, the raw materials provided are not fully met, the equipment and facilities for medical device procurement are inadequate, policies related to medical device maintenance have been well socialized planning for medical device maintenance activities is carried out every year, the organizational structure and division of labor do not have hambata, the implementation that is carried out refers to the program and operational standards (SPO), the supervision of medical device maintenance activities includes inspection of maintenance activity reports, the maintenance evaluation system is running well .

Conclusion: In general, the Medical Device Maintenance Management Implementation System (IP3MRS) of Arifin Achmad Hospital, Riau Province as seen from the objectives of the researchers, related to human resources, availability of funds, availability of equipment and facilities, spare parts, maintenance policies, planning, organizing, monitoring, and evaluation. there are some that are not yet optimal

Suggestion: It is recommended to add human resources to anticipate the risk of workload, purchase of new parts needed so that damaged equipment can be handled more quickly, IP3MRS Building facilities and spare parts storage so that they can be separated so that staff can work properly

Keywords: Medical Tools, IP3MRS, POACE Management

\section{PENDAHULUAN}

Peralatan kesehatan yang memegang peranan penting dalam proses menyelenggarakan pelayanan kesehatan masyarakat. Pelayanan kesehatan perlu didukung adanya peralatan selalu dalam kondisi siap pakai dan layak berdasarkan fungsinya dengan 
baik. Menurut undang-undang RI No 56 tahun 2014, peralatan rumah sakit umum harus memenuhi standar sesuai dengan ketentuan peraturan perundang-undangan, Pelayanan penunjang nonklinik sebagaimana dimaksud dalam Pasal 25 huruf e meliputi pelayanan laundry atau linen, jasa boga atau dapur, teknik dan pemeliharaan fasilitas, pengelolaan limbah, ambulan, gudang, sistem informasi, pengelolaan gas medik, dan pengelolaan air bersih, pemulasaraan jenazah (Kemenkes RI, 2014).

Pemeliharaan merupakan suatu kegiatan yang bertujuan untuk menjaga atau memastikan bahwa keadaan bangunan beserta sarana dan prasarana dalam kondisi yang baik, dapat beroperasi sewajarnya, dan dapat diterima oleh standar yang ada. Kegiatan pemeliharaan peralatan sangat penting untuk diterapkan, terutama bangunan yang memiliki fungsi penting, seperti rumah sakit, Permasalahan utama yang sering timbul adalah bagaimana pelaksanaan organisasi manajemen pemeliharaan yang sebaiknya dilakukan oleh rumah sakit, guna untuk melaksanakan kegiatan pemeliharaan dapat dilaksanakan dengan baik, dengan biaya yang efisien (Pringgondani, 2013).

Berdasarkan hasil penelusuran dokumen laporan tahunan IP3MRS RSUD Arifin Achmad Provinsi Riau diketahui terdapat beberapa indikator kinerja IP3MRS yang belum mencapai target seperti kecepatan waktu menanggapi kerusakan alat dengan pencapaian hanya 0,94\% dari target 15 menit realisasinya ( dari 956 laporan kerusakan) yang diterima sebanyak 9 laporan yang ditanggapi lebih dari 15 menit, ketepatan waktu pemeliharaan alat hanya $8,25 \%$ dari target $100 \%$ realisasinya ( dari total 3633 alat yang harus di lakukan pemeliharaan terencana, hanya sebanyak 300 alat yang terlaksana. serta jumlah peralatan medis yang harus dikalibrasi sebesar 6,95\% dari target alat mencapai 2587 realisasinya (180 alat yang terkalibrasi ) pada tahun 2019. Untuk kecepatan waktu menanggapi kerusakan alat ditahun 2020 dari bulan (Januari-Maret) target 100\% tidak ada keterlambatan waktu. Hal ini juga diperkuat dengan hasil wawancara yang dilakukan penulis kepada kepala instalasi IP3MRS merujuk pada laporan tahunan IP3MRS RSUD Arifin Achmad Provinsi Riau tahun 2019 diketahui bahwa dalam upaya pengelolaan pemeliharaan alat medis rumah sakit terdapat berbagai hambatan seperti kurangnya sumber daya manusia yaitu tenaga elektromedis khususnya laki-laki sehingga program pemeliharaan preventif kurang optimal, ruangan kerja yang kurang memadai, kurangnya peralatan kalibrasi serta tidak tersedianya spare part rutin untuk penggantian alat-alat yang rusak. dan suku cadang yang dimiliki oleh instalasi masi belum memadi mengakibatkan pekerjaan pemeliharaan (kalibrasi uji kesesuaian) dan perbaikan pada peralatan medis mengalami keterlambatan waktu. 
Kondisi siap pakai dan kelaikan peralatan medis sangat dipengaruhi oleh tingkat pemeliharaannya, agar dapat mencegah potensi terjadinya disfungsi dan kerusakan alat. Untuk dapat mewujukan pemeliharaan alat elektromedis yang baik, maka dibutuhkan sebuah sistem manajerial yang tertata dengan dengan baik juga, mulai dari faktor Input (masukan), antara lain sumberdaya yang dipergunakan antara lain kemampuan sumberdaya manusia yang dimiliki, standar operasional yang ditetapkan, sistem penganggaran dana pemeliharaan, sarana dan prasarana sebagai penunjang kegiatan pemeliharaan yang dipergunakan, serta faktor Proses yang meliputi pelaksanaan dan penerapan kegiatan (program-program) pemeliharaan yang terencana dan terorganisir dengan sistem manajerial dan administrasi yang tertata, teratur dan terkontrol dengan baik, sehingga menghasilkan Output (Keluaran) yaitu berupa peralatan medis yang ada di rumah sakit yang siap dan layak pakai saat dibutuhkan

Dalam penelitian ini, penulis ingin mengetahui mengenai evaluasi komponen input dan proses yang mempengaruhi keberlangsungan dan keberhasilan output yang ditetapkan. pada tahap masukan (input) sistem terdiri dari unsur manajemen yaitu komposisi sumber daya manusia pemeliharaan alat medis (man), sistem pendanaan pemeliharaan alat medis (money), bahan baku/perlengkapan pemeliharaan alat medis (materia), peralatan/fasilitas pemeliharaan alat medis (machine), kebijakan pemeliharaan alat medis (methode). Sedangkan dalam tahapan proses sistem terdiri variabel yang meliputi rangkaian proses manajemen POACE yaitu perencanaan dalam pemeliharaan alat medis, pengorganisassian, sistem pengawasan dan pelaksanaan evaluasi.

\section{METODE}

Rancangan Penelitian ini merupakan penelitian kualitatif dengan pendekatan deskriptif, observasi dan telaah dokumen, Penelitian ini akan dilakukan di Rumah Sakit Umum Daerah Arifin Achmad Provinsi Riau. Penelitian ini dilakukan bulan September 2020. Kepada 5 Informan yang terdiri 4 orang informan pangkal, 1 orang informan kunci.

\section{HASIL}

Hasil penelitian ini didapat berdasarkan wawancara mendalam, observasi dan penelusuran dokumen terhadap variabel penelitian manajemen instalasi pemeliharaan dan perbaikan pemeliharaan peralatan medis rumah sakit (IP3MRS) RSUD Arifin Achmad Provinsi Riau meliputi Sumber Daya Manusia (SDM), ketersediaan dana, ketersediaan peralatan dan fasilitas, ketersediaan suku cadang atau bahan baku, kebijakan, perencanaan, 
pengorganisasian, sistem pengawasan dan pelaksanaan evaluasi yang dilakukan pada instalasi pemeliharaan dan perbaikan pemeliharaan peralatan medis rumah sakit.

\section{Karakteristik Informan}

Berikut ini merupakan data karakteristik informan dengan hasil sebagai berikut:

\section{Karakteristik Informan}

\begin{tabular}{|l|c|c|c|c|c|l|}
\hline No & Kode & $\begin{array}{c}\text { Jenis } \\
\text { Kela } \\
\text { min }\end{array}$ & Pendidikan & Pekerjaan & $\begin{array}{c}\text { Lama } \\
\text { Bekerja }\end{array}$ & \multicolumn{1}{|l|}{ Keterangan } \\
\hline 1 & IP 1 & L & D3 Atem & Kepala IP3MRS & 14 Th & $\begin{array}{l}\text { Informan } \\
\text { Pangkal 1 }\end{array}$ \\
\hline 2 & IP 2 & L & D3 Atem & Karu IP3MRS & 10 Th & $\begin{array}{l}\text { Informan } \\
\text { Pangkal 2 }\end{array}$ \\
\hline 3 & IP 3 & P & Skm & $\begin{array}{c}\text { Teknisi/Pemelihara } \\
\text { alat medis }\end{array}$ & 10 Th & $\begin{array}{l}\text { Informan } \\
\text { Pangkal 3 }\end{array}$ \\
\hline 4 & IP 4 & P & S.Kom & $\begin{array}{c}\text { Fasilitas Pelayanan } \\
\text { medik }\end{array}$ & 9 Th & $\begin{array}{l}\text { Informan } \\
\text { Pangkal 4 }\end{array}$ \\
\hline 5 & IK & P & $\begin{array}{c}\text { Magister } \\
\text { Manajeme }\end{array}$ & Pengadaan & 8 Th & Informan Kunci \\
& & & n & & & \\
\hline
\end{tabular}

\section{Hasil Wawancara}

\section{a. Komposisi Sumber Daya Manusia (Man)}

Tim Pelaksana pemeliharaan alat medis berjumlah 8 orang, Tingkat Pendidikan petugas pemeliharaan alat medis DIII Teknis Medis, Petugas IP3MRS sejauh ini memiliki kinerja baik, Pengalaman petugas sudah lebih dari 1 tahun namun memiliki kemampuan kurang, Dibutuhkan minimal D III Teknis medis dalam pemeliharaan alat medis, Kekurangan SDM dalam hal ketenagaan pemeliharaan alat medis, Rumah Sakit belum memberikan upaya pelatihan terkait pemeliharaan alat medis dalam 1 tahun terakhir.

\section{b. Sistem Pendanaan Alat Medis (Money)}

Unit Teknik membuat perencanaan anggaran seluruh program kerja, Staf IP3MRS tidak mengetahui detail anggaran IP3MRS, Jenis biaya untuk kegiatan pemeliharaan alat medis terdiri dari anggaran perbaikan, anggaran pengadaan suku cadang, anggaran pengadaan alat medis baru, serta anggaran kegiatan operasional 
seperti biaya kalibrasi alat medis, Dana untuk program kegiatan pemeliharaan alat medis sudah cukup memadai, dan tidak memiliki kendala yang berarti.

\section{c. Bahan baku/perlengkapan alat medis (Material)}

Pembelian bahan baku wewenang bagian fasmed, Pembelian barang berdasarkan hasil evaluasi, Proses verifikasi (waktu) menjadi kendala dalam pengadaan, Tidak semua barang yang diajukan disetujui.

\section{d. Peralatan/Fasilitas (Machine)}

Fasilitas yang dilakukan pemeliharaan meliputi seluruh peralatan medis, Terdapat peralatan medis yang sudah tua dan harus diganti, Peralatan pemeliharaan alat medis sudah tersedia, Pemeliharaan dan perbaikan alat yang harus dikalibrasi tanggung jawab adalah IP3MRS baik itu dari alat-alat medis maupun non medis.

\section{e. Kebijakan Pemeliharaan Alat Medis (Methode)}

Kebijakan pemeliharaan alat medis berdasarkan kebijakan pemerintah, Tata Kerja Individu (TKI) atau Standard Operating Prosedure (SOP) untuk setiap alat sejauh ini sudah tersedia baik, Proses sosialisasi pemeliharaan alat medis sudah dilaksanakan

\section{f. Perencanaan Program Pemeliharaan Alat Medis (Planning)}

Perencanaan kegiatan pemeliharaan dibuat unit semua staf IP3MRS, Rencana kegiatan dibuat Staf IP3MRS atas persetujuan kepala IP3MRS, Penanggung jawab program rencanaan jadwal kegiatan adalah Kepala IP3MRS, Perencanaan memuat kegiatan yang akan dilakukan, waktu pelaksanaannya, serta kapan realisasi kegiatan.

\section{g. Pengorganisasian Program Pemeliharaan Alat Medis (Organizing)}

Struktur kegiatan pemeliharaan alat medis merupakan tanggung jawab dari Unit IP3MRS, Kriteria dalam penempatan petugas pemeliharaan alat medis adalah berdasarkan latar belakang dan tingkat pendidikan minimal, Sistem pembagian kerja dalam kegiatan pemeliharaan alat medis sejauh ini sudah jelas.

\section{h. Pelaksanaan Program Pemeliharaan Alat Medis (Actuating)}

Pelaksanaan kegiatan pemeliharaan alat menjadi tanggung jawab dari Unit Teknik, yang pelaksanaannya dipegang langsung oleh Kepala IP3MRS, Pelaksanaan kegiatan pemeliharaan alat medis sudah mengacu kepada kebijakan dan prosedur yang ada, Proses mobilisasi petugas dalam pelaksanaan kegiatan pemeliharaan alat 
medis sejauh ini tidak memiliki kendala, Pelaksanaan kegiatan pemeliharaan alat medis belum diadakannya bentuk reward dan punishment khusus.

\section{i. Sistem pengawasan Alat Medis}

Pengawasan meliputi pemantauan terhadap laporan pelaksanaan kegiatan pemeliharaan alat kesehatan secara umum, Pengawasan kegiatan pemeliharaan alat medis berdasarkan pada realisasi pemeliharaan, perbaikan dan kegiatan harian, serta kalibrasi alat, Kegiatan pengawasan terhadap kegiatan pemeliharaan alat medis di RS Arifin Achmad tergolong sudah cukup efektif, Proses pengawasan oleh penanggung jawab kegiatan pemeliharaan alat medis di RS Arifin Achmad telah melakukan dokumentasi.

\section{j. Evaluasi Kegiatan Pemeliharaan Alat Medis}

Evaluasi pelaksanaan pemeliharaan alat kesehatan terbagi menjadi dua jenjang evaluasi, Unit Teknik RS Arifin Achmad belum memiliki formulir checklist secara spesifik terhadap penilaian alat medis, Hasil dari penilaian kondisi alat secara internal tersebut didokumentasikan dalam bentuk daftar inventaris, Kegiatan pemeriksaan alat medis secara rutin didokumentasikan ke dalam bentuk laporan pemeriksaan alat yang ditanda tangani oleh user pengguna alat.

\section{PEMBAHASAN}

1. Keterbatasan, adapun keterbatasan dalam penelitian yang dilakukan tentang Evaluasi sistem Pelaksanaan Manajemen Pemeliharaan Alat Medis Di Instalasi Pemeliharaan dan Perbaikan Peralatan Medis Rumah Sakit (IP3MRS) RSUD Arifin Achmad Provinsi Riau antara lain:

a. Sulitnya mengatur waktu wawancara dengan informan khususnya informan kunci dan informan pengkal kode 4 akibat kesibukan masing-masing dalam tugas kerja. Situasi ini membuat peneliti berulang kali menjadwalkan proses wawancara dengan informan sehingga waktu penelitian mundur dari jadwal yang sudah ditentukan.

b. Ada beberapa kencendrungan informan merespon pertanyaan dari peneliti dengan jawaban yang subjektif. Seperti menghindari jawaban yang sebenarnya, hal ini yang mendasari untuk beberapa pertanyaan.

c. Peneliti memiliki keterbatasan waktu dan akses selama penelitian. hal ini disebabkan RSUD Arifin Achmad sebagai salah satu Rumah Sakit rujukan kasus COVID-19 di Provinsi Riau.

\section{Pembahasan Hasil}

\section{a. Komposisi Sumber Daya Manusia (Man)}

Berdasarkan hasil peneliti yang dilakukan melalui wawancara mendaalam dengan informan terkait pemeliharaan sarana rumah sakit di RS Arifin Achmad 
terkait sumber daya manusia dalam manajemen pemeliharaan merupakan tenaga atau personal yang memiliki keahlian dalam bidang pemeliharaan sesuai dengan spesifikasi jenis pemeliharaan. Serta mampu mengupayakan kegiatan-kegiatan pemeliharaan sesuai dengan standar yang diberlakukan, permasalahan terkait sumber daya manusia diinstalasi Pemeliharaan Alat Medis Di Instalasi Pemeliharaan Dan Perbaikan Peralatan Medis Rumah Sakit (IP3MRS) adalah walaupun sudah ada pembagian tugas namun untuk semua tugas masi cenderung dihendal oleh semua petugas IP3MRS dikarenakan jumlah petugas terdiri dari delapan orang. Kondisi tertentu itulah yang membuat hasil kerja pemeliharaan tidak efektif, hal tersebut dikarenakan kelelahan dan beban kerja yang seharusnya bukan dikerjakan oleh petugas tersebut dan jumlah alat-alat dirumah sakit jumlahnya tidak sedikit, oleh sebab itu pihak IP3MRS menggunakan pihak ke tiga dalam penyelesaian tugasnya.

Berdasarkan pada Pasal 17 Undang-undang Nomor 28 tahun 2013 tentang jabatan fungsional teknisi elektromedis, bahwa sejauh ini kegiatan pemeliharaan alat elektromedik di RS Arifin Achmad pada dasarnya belum memenuhi standar formasi dalam hal ini petugas pelaksana kegiatan pemeliharaan alat medis yang berlatar belakang dan tingkat pendidikan Diploma III Elektromedik hanya 7 orang dari 8 tenaga kerja staf di IP3MRS. formasi jabatan fungsional teknisi elektromedis sebagai mana dimaksud bahwa dilingkungan rumah sakit umum untuk kelas tipe $B$ untuk tenaga terampil berjumlah 24 orang dan tenaga ahli 12 orang, sehingga untuk kegiatan pemeliharaan dan perbaikan sarana rumah sakit belum efektif. Hal ini disebabkan faktor kelelahan dan beban kerja.

Temuan data hasil penelitian diatas dengan temuan Observasi, dimana ketersediaan sumber daya manusia oleh IP3MRS baik dari segi jumlah petugas dan kesesuaian kualifikasi petugas dengan job yang dibutuhkan belum terpenuhi. Walaupun secara umum petugas yang ada mampu mengatasi permasalahan pemeliharaan dan perbaikan alat-alat medis di rumah sakit namun untuk masalah penanganan yang serius tentu masi menggunakan pihak dari luar atau pihak ke tiga.

Menurut mangkunegara (2009) sumber daya manusia merupakan modal kekayaan yang terpenting dari setiap kegiatan manusia. Manusia sebagai unsur terpenting mutlak, dianalisis dan dikembangkan dengan cara tersebut, waktu tenaga dan kemampuan benar-benar dimanfaatkan secara optimal bagi kepentingan organisasi maupun kepentingan individu. Sumber daya manusia juga adalah tenaga dan kemampuan, keahlian yang dimiliki oleh manusia. 
Hal ini sesuai dengan Keputusan Menteri Pendayaan Aparatur Negara Nomor: 41/Kep/M. Pan/4/2003 tentang Jabatan Fungsional Teknisi Elektromedis dan Angka Kreditnya bahwa petugas yang berwenang dalam melakukan kegiatan teknik elektromedik pada unit pelayanan kesehatan adalah seorang teknisi elektromedik.

Berdasarkan hasil penelitian terkait sumber daya manusia bahwasanya sebagai petugas penanggung jawab dan pelaksana harian kegiatan pemeliharaan alat medis dirumah sakit, selain latar belakang pendidikan minimal Diploma III Elektromedik yang dimiliki, maka juga harus disertai dengan pengalaman kerja sesuai dengan bidang pemeliharaan alat kesehatan khususnya alat elektromedik sekurang-kurangnya satu tahun, tujuan agar kinerja sumberdaya manusia yang dimiliki benar-benar matang dalam bidangnya.

Penelitian ini sesuai dengan penelitian candra (2016) dimana hasil penelitiannya juga menunjukkan sumber daya manusia dalam unit masih dibutuhkannya penataan manajemen, masih banyak tenaga itu sendiri yang belum memahami bidang apa yang dipegangnya masing-masing, itu disebabkan karena latar pendidikan serta pelatihan yang jarang dilakukan oleh teknisi.

Disarankan perlu adanya penambahan tenaga elektromedis berdasarkan aspek kualifikasi kompetensinya yang seharusnya agar perbaikan dan pemeliharaan peralatan medis rumah sakit dapat dilaksanakan dengan maksimal. Sehingga meminimalisir kelelahan dan beban kerja petugas.

\section{b. Sistem Pendanaan Alat Medis (Money)}

Pada kegiatan pendanaan atau penganggaran, hal yang terpenting selain dana atau uang adalah sistem pendanaan itu sendiri, bagaimana proses pendanaan, mulai dari perencanaan atau penganggaran dana, penggunaan atau pembelanjaan dana, hingga kepada pencatatan dan evaluasi dana yang digunakan, serta pengawasan dalam penggunaan dana, karena sebuah alur pendanaan sangat erat kaitannya dengan sistem administrasi dalam pendanaan.

Dalam kegiatan pemeliharaan di rumah sakit, khususnya pemeliharaan alat-alat medis, maka dana merupakan salah satu faktor penting dalam menunjang kelancaran dan keberlangsungan proses kegiatan pemeliharaan. Tanpa dana dan sistem pendanaan yang baik, maka kegiatan pemeliharaan akan menjadi terkendala, karena memang operasional pemeliharaan tersebut sangat erat kaitannya dengan kegiatan pengecekan, perbaikan dan pergantian alat yang tentunya membutuhkan bahan baku atau perlengkapan penunjang secara 
kontinyu. Unit teknis RS Arifin Achmad pada dasarnya sudah memiliki perencanaan anggaran untuk kegiatan pemeliharaan alat medis, namun perencanaan anggaran tersebut hanya disusun berdasarkan kebutuhan kegiatan yang berjalan, kebutuhan tersebut didapat dari laporan dan permintaan operator pengguna alat (user) jika terjadi kerusakan atau membutuhkan pengadaan alat yang baru, serta juga didapatkan dari hasil evaluasi kebutuhan berjalan yang disusun oleh petugas pemelihara alat medis itu sendiri.

Berdasarkan hasil wawancara mendalam dalam terkait penyedian angaran pemeliharaan sarana rumah sakit umum daerah Arifin achmad seluruh informan sepakat tentang kecukupan anggaran pemeliharaan. Dalam hal pencairan dana yang bersifat urgent, maka dapat dilakukan dengan pengajuan Panjar Kerja, dimana petugas dapat mengajukan kebutuhan dana secara langsung kepada Bagian Keuangan dengan persetujuan Wadir SDM dan Umum melalui Kepala Unit Teknik. Kemudian untuk sistem pelaporan Panjar Kerja dilakukan pada saat kegiatan telah dilaksanakan, kemudian disusun kedalam bentuk Pertanggung Jawaban Panjar Kerja yang dilaporkan kepada Bagian Keuangan, berisikan laporan kegiatan dan penggunaan serta peruntukan dana yang telah dikeluarkan. Perencanaan dana di Unit Teknik pada umumnya hanya meliputi perencanaan, pemakaian dan pelaporan hasil pemakaian dana tersebut, terdiri dari pendokumentasian biaya yang dikeluarkan, kemudian untuk proses akuntansi dan keuangan ditangani oleh Bagian Keuangan sebagai pengawas dan pengelola keuangan rumah sakit. Secara umum sistem pendokumentasian biaya yang telah dilakukan sudah cukup baik dalam rangka memonitor pemakaian dan peruntukan dana, serta dapat digunakan sebagai evaluasi penganggaran dalam kegiatan pemeliharaan alat Kesehatan. Untuk alokasi anggaran pemeliharaan dan perbaikan alat-alat medis menunjukan ketersediaan anggaran pemeliharaan alatalat medis, alokasi anggaran relatif mencukupi.

Menurut sabarguna (2011) bahwa dalam melaksanakan pemeliharaan dan perbaikan alat-alat medis diperlukan biaya, permasalahannya berapa besar biaya yang diperlukan. Manfaat yang lebih penting adalah bila pemeliharaan dilakukan dengan tepat untuk menjamin sarana dan alat siap pakai, biaya akan lebih murah dibandingkan dengan perbaikan yang terlalu berat, serta dapat menjunjung mutu keamanan dan kepuasan pasien.

Penelitian ini sesuai dengan penelitian Hutomo (2013) yang juga menemukan belum akuratnya penggaran alokasi dana untuk pemeliharaan sarana rumah sakit Al-Huda Banyuwangi yang membuat anggaran yang tersedia 
tidak sesuai dengan kebutuhan pemeliharaan sarana rumah sakit. Hal ini disebabkan data pemakain bahan, material dan peralatan tidak terdokumentasi dengan baik, sehingga kurang efektif dalam memprediksi kebutuhan belanja bahan untuk tahun selanjutnya.

Terkait anggaran pemeliharaan di IP3MRS Rumah sakit Arifin Achmad Pekanbaru Riau, sejauh ini kebutuhan dana pemeliharaan alat tidak memiliki kendala, secara umum sudah sesuai prosedur. hal tersebut dikarenakan pada saat proses pengajuan permintaan pencairan dana untuk kegiatan pemeliharaan melalui sistem request yang disertai dengan dasar permintaan yang diperoleh dari hasil laporan pemeriksaan. Namun dari seluruh dana yang diberikan sudah cukup untuk masalah pemeliharaan.

Simpulan dari peneliti terkait anggaran pemeliharaan di IP3MRS Rumah sakit Arifin Achmad Pekanbaru Riau, sejauh ini kebutuhan dana pemeliharaan alat tidak memiliki kendala, hal tersebut diakrenakan pada saat proses pengajuan permintaan pencairan dana untuk kegiatan pemeliharaan melalui sistem request yang disertai dengan dasar permintaan yang diperoleh dari hasil laporan pemeriksaan.

\section{c. Bahan Baku/Perlengkapan Pemeliharaan Alat Medis (Material)}

Seperti halnya dana (money), didalam kegiatan pemeliharaan pemeliharaan di rumah sakit khususnya pemeliharaan elektromedik, bahan baku atau perlengkapan (materia) merupakan salah satu faktor penting yang dibutuhkan dalam menunjang kelancaran dan keberlangsungan proses kegiatan pemeliharaan. Tanpa bahan baku atau perlengkapan yang memadai, maka proses kegiatan pemeliharaan akan sulit untuk dilakukan. Uniknya setiap alat medis, membutuhkan bahan baku atau perlengkapan (material) yang memiliki spesifikasi tersendiri, beda alat makan beda bahan baku yang dibutuhkan. Maka diperlukan sebuah sistem manajemen yang baik dalam perencanaan, pengadaan dan penggunaan bahan bahan baku atau perlengkapan (material) yang diperlukan guna menunjang kelancaran dan keberlangsungan kegiatan pemeliharaan.

Alamsyah (2011) menegaskan bahwa dalam proses pelaksanaan kegiatan, sumber daya manusia membutuhkan dan menggunakan bahan baku atau perlengkapan, karenanya maka bahan baku dan perlengkapan (material) juga disebut sebagai sarana atau alat manajemen untuk mencapai tujuan.

Proses pengadaan dan pembelian barang untuk kegiatan pemeliharaan alat medis pada dasarnya sama seperti proses pengadaan dan pembelian barang pada 
umumnya. Unit-unit yang terlibat dalam proses pengadaan dan permintaan tersebut yaitu Unit Keuangan, serta Wadir pelayanan medis dan keperawatan dan kabid fasilitas pelayanan medik.

Berdasarkan hasil penelitian yang dilakukan melalui wawancara mendalam, dengan informan terkait ketersediaan bahan baku atau perlengkapan ketersediaan alat diruamah sakit Arifin Achmad belum sepenuhnya terpenuhi, Hal tersebut dilihat dari segi kuatitas suku cadang dan bahan baku, sejauh ini Unit teknik sedikit mengalami kekurangan, namun untuk beberapa peralatan yang tidak diproduksi lagi oleh pihak produser, maka mengalami hambatan dalam pencarian suku cadang atau bahan baku yang sesuai dengan alat tersebut, solusinya jika memang tidak tersedia dipasaran, maka akan dilakukan kajian lebih lanjut mengenai tingkat kebutuhan pengadaan unit peralatan yang baru.

Penelitian ini berbeda dengan penelitian yang dilakukan oleh roman dalam Gita (2019) dimana penyediaan material dalam pemeliharaan sarana rumah sakit di rumah sakit Baladhika Husada Jember sudah baik mampu mangantisipasi kebutuhan material Ketika mengalami kerusakan atau masa waktu pemakaiannya suatu bahan telah sampai waktunya untuk diganti, hampir semua kebutuhan material distock digudang logistik dimana hal ini belum dapat diaplikasikan sebagai temuan dalam penelitian ini yang hanya mampu menyediakan bahan material untuk bahan-bahan pengguananya relative mudah untuk diprediksi.

Berdasarkan hasil observasi dan telaah dokumen yang dilakukan peneliti didapatkan bahwa standar pelayanan minimal dan yang terjadi dilapangan masi mengalami kendala yang selama ini dihadapi pada lamanya barang datang, hal tersebut membuat ketepatan waktu pemeliharaan mengalami kendala di tahun 2019 untuk kecepatan waktu menanggapi kerusakan alat dari total 956 laporan kerusakan yang diterima oleh IP3MRS sebanyak 9 laporan yang ditanggapi lebih dari 15 menit, penyebab belum dapat dikerjakan karena pekerjaan perbaikan tersebut membutuhkan pihak ke 3 (21\%) ataupun sole agent dengan menggunakan anggaran pemeliharaan. Justifikasi telah diusulkan ke Wadir dan Keperawatan melalui Bidang Fasilitas Pelayanan Medik.

Tabel 5.1 Standar Pelayanan Minimal IP3MRS di Instalasi Pemeliharaan Dan Perbaikan Peralatan Medis Rumah Sakit (IP3MRS) RSUD Arifin Achmad Provinsi Riau 


\begin{tabular}{|l|l|l|}
\hline No & \multicolumn{1}{|c|}{ Indikator } & \multicolumn{1}{c|}{ Target } \\
\hline 1. & Kecepatan waktu menanggapi kerusakan alat & 15 Menit \\
\hline 2. & Ketepatan waktu pemeliharaan alat & $100 \%$ \\
\hline 3. & Jumlah peralatan medis yang harus dikalibrasi & $100 \%$ \\
\hline
\end{tabular}

Diagram Pencapaian Target di Instalasi Pemeliharaan Dan Perbaikan Peralatan Medis Rumah Sakit (IP3MRS) RSUD Arifin Achmad Provinsi Riau Tahun 2019

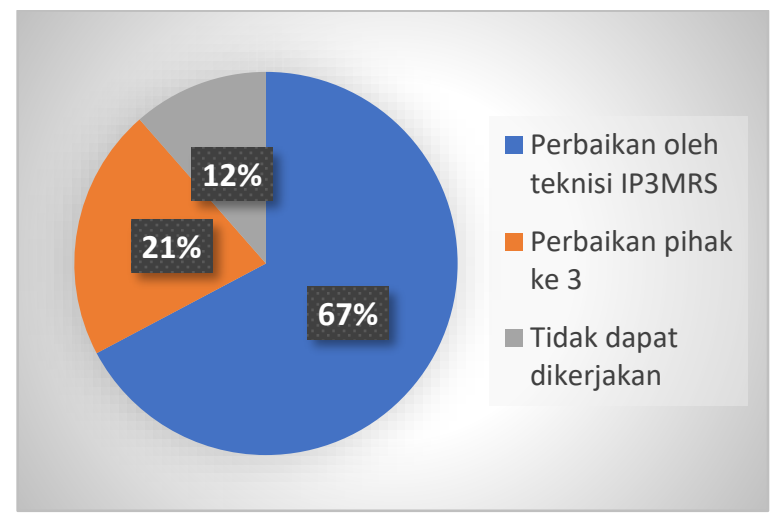

Disarankan untuk ketersediaan bahan baku dan perlengkapan ketersediaan alat dirumah sakit Arifin Achmad agar dilakukan penambahan atau upgrade, selain itu kebutuhan material distock digudang logistik harapannya agar pada saat dibutuhkan tidak memakan waktu dan segera bisa ditangani.

\section{d. Peralatan/Fasilitas (Machine)}

Untuk melakukan kegiatan yang cepat dan tidak sepenuhnya menggunakan manusia maka dibutuhkan mesin sebagai kegiatan untuk mencapai tujuan. (Alamsyah, 2011).

Peralatan (machine) baik itu peralatan pokok seperti komponen atau set alat petugas pemeliharaan mekanik ataupun elektro, maupun peralatan (machine) penunjang kegiatan pemeliharaa seperti komputer dalam mengolah dan menyimpan data administrasi kegiatan pemeliharaan merupakan salah satu faktor penting yang dibutuhkan dalam menunjang kelancaran dan keberlangsungan 
proses kegiatan pemeliharaan. Tanpa peralatan (machine) yang memadai, maka proses kegiatan pemeliharaan akan sulit untuk dilakukan.

Berdasarkan hasil wawancara mendalam yang dilakukan kepada petugas IP3MRS, diketahui bahwa ada beberapa alat yang mungkin sekiranya dapat dipertimbangkan untuk dilakukan pengadaan agar lebih dapat menunjang kegiatan pemeliharaan secara lebih baik kedepannya. Akan tetapi pada prinsipnya beberapa peralatan yang masih dinilai kurang oleh petugas pemelihara alat medis tersebut tidak begitu prinsipil untuk diadakan, karena sejauh ini untuk mengatasi permasalahan terkait keterbatasan peralatan dalam melakukan pemeliharaan, sudah dapat diantisipasi dengan adanya kerjasama dengan pihak vendor ataupun supplyer alat kesehatan, kerjasama tersebut dalam hal pemeliharaan dan perbaikan. Pada intinya penambahan peralatan maupun fasilitas kegiatan pemeliharaan tentunya membutuhkan kajian dan evaluasi secara lebih lanjut di luar penelitian ini.

\section{Diagram Total Alat yang harus dilakukan Pemeliharaan Dan Perbaikan Peralatan Medis Rumah Sakit (IP3MRS) RSUD Arifin Achmad Provinsi Riau} Tahun 2019

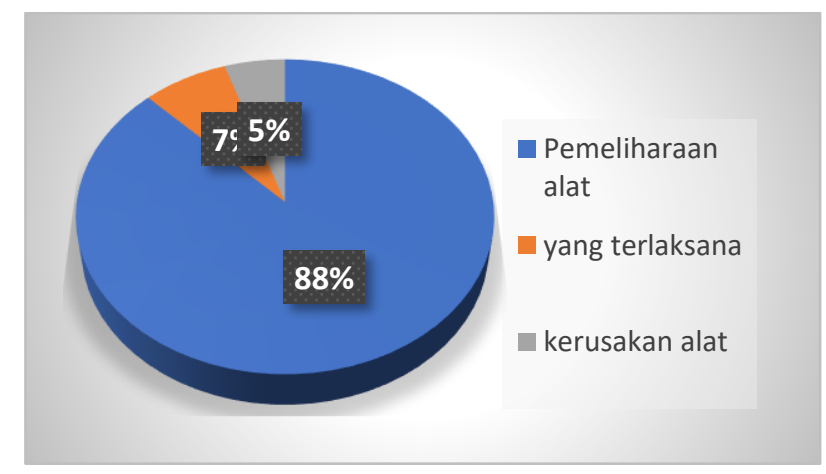

Berdasarkan hasil observasi dan telaah dokumen diketahui bahwa untuk alat-alat yang harus dipelihara oleh rumah sakit Arifin Achmad dari total 3633 alat yang harus dilakukan pemeliharaan terencana, hanya sebanyak 300 alat yang terlaksana dan untuk laporan pemeliharaan dan alat yang rusak sebanyak 213. Tentunya beragam dari jenis alat-alat yang memerlukan upaya pemeliharaan, maka dalam menunjang kegiatan pemeliharaan alat-alat elektromedik, rumah sakit Arifin Achmad menyediakan berbagai peralatan dana fasilitas pendukung lainnya guna untuk kegiatan pemeliharaan. Sedangkan untuk fasilitas pendukung kegiatan 
pemeliharaan alat elektromedik terdiri dari ruang kepala IP3MRS, ruang administrasi yang dilengkapi 2 komputer, dan ruang teknik yang menyatu dengan ruangan perbaikan pemeriksaan dan belum adanya gudang khusus penyimpanan suku cadang digedung IP3MRS.

Secara kuantitas, ketersediaan fasilitas dan peralatan pemeliharaan alat medis belum memadai yang dilihat dari beberapa aspek yaitu terkait jumlah alat yang berada dirumah sakit dengan jumlah yang tidak sedikit yang harus dipelihara, dan terkait fasilitas Gedung IP3MRS yang belum mempunyai gudang khusus dikarenakan gudang penyimpanan suku cadang dan ruang kerja masi menyatu.

Disarankan untuk kedepannya, guna lebih menunjang kegiatan pemeliharaan alat medis, maka perlu dilakukan evaluasi terhadap ketersediaan peralatan atau fasilitas pemeliharaan alat elektromedik yang saat ini dimiliki, terutama gudang dan gedung penyimpanan.

\section{e. Kebijakan Pemeliharaan Alat Medis (Methode)}

Dari hasil penelitian yang diperoleh dari informan terkait kebijakan Pelaksanaan Manajemen Pemeliharaan Alat Medis Di Instalasi Pemeliharaan dan Perbaikan Peralatan Medis Rumah Sakit (IP3MRS) kebijakan merupakan faktor yang sangat dibutuhkan dalam menjalankan kegiatan, baik itu kegiatan pemeliharaan secara menyeluruh, mengenai manajerial dan administrasi.

Untuk melakukan kegiatan berdaya guna atau berhasil guna, manusia dihadapkan kepada berbagai alternatif-alternatif cara melakukan suatu pekerjaan. Oleh karena itu metode atau cara dianggap pula sebagai sarana atau alat manajemen untuk mencapai suatu tujuan. (Alamsyah, 2011).

Dalam kegiatan pemeliharaan di rumah sakit, khususnya pemeliharaan alat medis. Kebijakan atau metode (method) merupakan faktor yang dibutuhkan dalam memformulasikan mengenai dasar, cara dan prosedur dalam melakukan kegiatan pemeliharaan. Baik itu kegiatan pemeliharaan secara menyeluruh, mengenai sistem manajerial dan administrasinya. Maupun kegiatan pemeliharaan khusus terhadap alat-alat yang harus dipelihara. Kebijakan atau metode (method) tentunya merujuk pada peraturan pemerintah dan sistem prosedur rumah sakit yang telah ditetapkan.

Dalam pelaksanaan pemeliharaan diperlukan metode yang didalamnya terdapat pedoman yang berisi prosedur-prosedur oprasional standar yang ada dalam suatu organisasi yang gunanya untuk memutuskan bahwa setiap keputusan Langkah atau tindakan dan penggunaan fasilitas pemrosesan yang dilaksanakan 
oleh orang-orang didalam suatu organisasi telah berjalan efektif, berstandar, konsisten dan sistematis.

Menurut penelitian (Astuti, 2015) kebijakan atau metode merupakan faktor yang dibutuhkan dalam menginformasikan mengenai dasar, prosedur dan cara dalam melakukan kegiatan pemeliharaan.

Berdasarkan hasil observasi dan telaah dokumen diketahui bahwa untuk landasan kebijakan yang dijadikan acuan dalam pekerjaan di IP3MRS adalah:

A. Undang-undang nomor 36 tahun 2009 tentang kesehatan

B. Keputusan Menteri Kesehatan No. 371/MENKES/SK/III/2007 tentang Standar Profesi Elektromedis.

C. Ketentuan Pelaksanaan Jabatan Fungsional Teknisi Elektromedis oleh Badan Kepegawaian Negara Tahun 2015.

D. Keputusan Menteri Pendaya Aparatur Negara Nomor: 41/Kep/M.Pan/4/ 2003 tentang jabatan fungsional teknisi elektromedis

E. Pedoman dan pengujian dan Kalibrasi alat kesehatan oleh direktorat jendral pelayanan medik tahun 2001

Sejauh ini kebijakan dan metode yang ada di IP3MRS rumah sakit umum daerah Arifin Achmad Pekanbaru Riau sudah berjalan dengan baik dan sesuai dengan standar prosedur oprasional yang ada.

\section{f. Perencanaan Program Pemeliharaan Alat Medis (Planning)}

Perencanaan adalah sebuah proses yang dimulai dengan merumuskan tujuan dari sebuah organisasi atau instritusi sampai dengan alternatif kegiatan mencapainya. Tanpa ada fungsi perencanaan sebuah organisasi atau institusi, tidak ada kejelasan kegiatan yang akan dilaksanakan oleh staf untuk mencapai tujuan sebuah organisasi atau institusi.

Menurut sulaeman (2009) menegaskan bawa yang terpenting bukanlah hasil atau perangkat perencanaan melainkan proses perencanaan itu sendiri. Untuk keberhasilan pekerjaan perencanaan, sangat dianjurkan untuk memahami proses perencanaan. Proses perencanaan sebuah organisasi atau institusi harus melibatkan seluruh unsur yang terkait secara partisifatif.

Berdasarkan hasil wawancara mendalam, dalam kegiatan pemeliharaan alat medis, Unit IP3MRS sejauh ini telah memiliki perencanaan yang dibuat pada setiap awal tahun. Rencana tersebut tergabung ke dalam rencana kegiatan pemeliharaan alat kesehatan Unit Teknik RS Arifin Achmad. Perencanaan yang dilakukan berupa pembuatan jadwal kegiatan pemeliharaan, sedangkan untuk tujuan kegiatan pemeliharaan alat kesehatan dalam hal ini alat elektromedik sudah termuat di dalam Tata Kerja Organisasi (TKO) Unit Teknik, yang pada intinya bahwa Kegiatan 
pemeliharaan alat kesehatan adalah bertujuan untuk mencegah terjadinya kerusakan alat dan memperpanjang umur alat agar peralatan yang ada selalu dalam kondisi baik, siap pakai dan memberikan keamanan bagi user dan pengguna dalam mendukung operasional RS Arifin Achmad. Serta mendeteksi kerusakan alat sedini mungkin dan mencegah terjadinya kontaminasi.

Jika dilihat dari pemaparan diatas, maka program pemeliharaan tersebut sudah sangat sesuai dengan kategori pemeliharaan yang dikemukakan oleh Sabarguna (2013) bahwa pada dasarnya sistem pemeliharaan itu terbagi menjadi dua macam, yaitu pemeliharaan terencana dan pemeliharaan tidak terencana.

\section{g. Pengorganisasian Program Pemeliharaan Alat Medis (Organizing)}

Pengorganisasian adalah kegiatan mengkelompokkan dan menentukan berbagai kegiatan penting dan memberikan kekuasaan untuk melaksanakan kegiatan-kegiatan itu. Selain itu pengorganisasian merupakan serangkaian kegiatan manajemen untuk menghimpun sumber daya yang dimiliki oleh sebuah organisasi atau institusi atas dasar pengertian tersebut, fungsi pengorganisasian juga meliputi proses semua sumber daya yang dimiliki sebuah organisasi atau institusi (Sulaeman, 2009).

Berdasarkan hasil penelitian yang dilakukan melalui wawancara mendalam dengan informan terkait Selama ini pembagian kerja dalam kegiatan pemeliharaan alat kesehatan khususnya alat medis dapat dibilang sudah cukup efektif dan sesuai dengan tujuan dari perorganisasian yang dipaparkan oleh beberapa informan. Efektifitas pembagian kerja dalam pemeliharaan alat kesehatan dalam hal ini alat medis tersebut dapat dilihat dari laporan realisasi pelaksanaan kegiatan pemeliharaan, perbaikan dan tugas harian serta program kalibrasi yang dilaksanakan per tahun secara umum sudah berjalan sesuai dengan jadwal kegiatan yang telah direncanakan.

Struktur organisasi pada kegiatan pemeliharaan alat medis sudah terlihat jelas dari observasi, tertempel didinding ruangan IP3MRS yang menunjukkan bagan organisasi instalasi pemeliharaan perbaikan dan peralatan medis rumah sakit (IP3MRS) serta visi misi yang juga tertempel disebelah struktur organisasi.

Dari hasil observasi dan telah dokumen sistem komunikasi internal di rumah sakit RSUD Arifin Achmad organisasi di IP3MRS langsung dikepalai oleh direktur rumah sakit RSUD Arifin Achmad Pekanbaru, dan dibawahi oleh wakil direktur bidang pelayanan medis dan keperawatan selanjutnya unruk seluruh alat di yang mengatur adalah kepala bidang fasilitas pelayanan medik dan selanjutnya yang 
bertanggung jawab adalah kepala instalasi pemeliharaan dan perbaikan dan peralatan medis rumah sakit (IP3MRS) Arifin Achmad Pekanbaru riau, dan ada enam staf yang bertanggung jawab terkait pelaksanaan kegiatan pemeliharaan.

Kemudian sistem komunikasi sudah terbilang efektif, dimana dari hasil wawancara mendalam, sistem komunikasi baik secara internal maupun ekternal sudah berjalan dengan baik guna mendukung keberlangsungan dalam pelaksanaan kegiatan pemeliharaan alat medis.

\section{h. Pelaksanaan Program Pemeliharaan Alat Medis (Actuating)}

Pelaksanaan kegiatan pemeliharaan alat medis secara penuh menjadi tanggung jawab dari Unit IP3MRS, yang pelaksanaannya dipegang langsung oleh Pengawas. Pergerakan merupakan proses bimbingan kepada staf agar mereka mampu dan mau bekerja secara optimal menjalankan tugas-tugasnya sesuai dengan kemapuan dan keterampilan yang dimiliki serta dukungan sumber daya yang tersedia. Kepemimpinan yang efektif, pengembangan motivasi, komunikasi, dan pengarahan sangat membantu suksesnya pelaksanaan fungsi aktuasi (Sulaeman,2009).

Dalam pelaksanaan pemeliharaannya diperlukan metode yang didalamnya terdiri dari pedoman yang berisi prosedur-prosedur oprasional standar yang ada dalam suatu organisasi yang digunakan untuk memutuskan bahwa setiap keputusan. Langkah atau tindakan pengunaan fasilitas pemrosesan yang dilaksanakan oleh orang-orang didalam suatu organisasi telah berjalan efektif.

Untuk dapat memastikan bahwa proses pengelolaan berjalan sesuai dengan ketentuan maka Unit Teknik membuat berbagai Standard Operating Prosedur (SOP) terkait kegiatan pemeliharaan alat medis dan pengoperasian alat medis. Tanggung jawab secara umum sesuai dengan Keputusan Menteri Kesehatan Nomor 371/ MENKES/ SK/ III/ 2007 adalah menjamin terselenggaranya pelayanan kesehatan khususnya kelayakan siap pakai peralatan kesehatan dengan tingkat keakurasian dan keamanan serta mutu yang standar. Sejauh ini pelaksanaan kegiatan pemeliharaan alat elektromedik di Unit Teknik RS Arifin Achmad sudah mengacu kepada kebijakan dan prosedur yang ada.

Pergerakan atau pelaksanaan sangat erat kaitannya dengan kemampuan seorang pimpinan dalam mengarahkan staf ataupun bawahannya agar dapat menjalankan fungsi dan tugasnya sesuai dengan jobdesnya masing-masing. Selain itu untuk menunjang program pelaksanaan kegiatan pemeliharaan alat medis alangkah baiknya dilakukan penghargaan sehingga tugas yang diemban 
dapat berjalan dengan maksimal, reward diartikan penghargaan meliputi banyak dari perangsang yang disediakan oleh organisasi sebagai bagian dari kontrak psikologis. Penghargaan juga memuaskan sejumlah kebutuhan yang berusaha untuk dipenuhi oleh karyawan melalui pilihan mereka atas perilaku terkait pekerjaan (Moorhead \& Griffin, 2013). Sedangkan Menurut Mangkunegara (2015) berpendapat bahwa Punishment adalah ancaman hukuman yang bertujuan untuk memelihara peraturan yang berlaku dan memberikan pelajaran kepada pelanggar

Berdasarkan wawancara belum diadakannya reward yang diberikan oleh Kepala IP3MRS hanya sebatas pemberian nilai baik dalam penilaian kerja. Sedangkan untuk phunishment sejauh ini belum dilakukan, karena memang pelaksanaan kegiatan sesuai dengan Standar Operating Prosedur (SOP) merupakan tanggung jawab yang secara langsung diemban oleh setiap petugas, belum ada sanksi yang diberikan kepada petugas Teknik khususnya petugas pemelihara alat elektromedik

Berdasarkan hasil observasi Adapun syarat-syarat umum yang wajib dilakukan dalam proses pelaksanaan kegiatan pemeliharaan yang sesuai dengan standar operating procedure (SOP) yang berlaku dirumah sakit RSUD Arifin Achmad:

a. Tim Pelaksanaa diwajibkan, berkonsultasi dengan kepala IP3MRS pada saat memulai pelaksanaan pekerjaan.

b. Tim Pelaksana harus bertanggung jawab atas kecelakan yang diakibatkan oleh kelalaian pekerjaan pada saat pelaksanaan kerja dalam pelaksanaan pekerjaan.

c. Tim pelaksana menyeidakan peralatan yang memadai dan sesuai, yang menjamin keselamatan kerja dalam proses pengerjaan.

d. Semua kebutuhan alat atau material menjadi tanggung jawab pelaksana. Seperti halnya yang dinyatakan oleh Muninjaya (2004) bahwa pergerakan adalah proses bimbingan kepada staf agar mereka mampu dan mau bekerja secara optimal menjalankan tugas-tugasnya sesuai dengan kemampuan dan keterampilan yang dimiliki, serta dukungan sumber daya yang tersedia. Kepemimpinan yang efektif, pengembangan motivasi, komunikasi, dan pengarahan sangat membantu suksesnya pelaksanaan fungsi aktuasi.

Dapat disimpulkan untuk tugas pelaksanaan kegiatan pemeliharaan alat medis sudah berjalan dengan baik, dimana pelaksana dijalankan merujuk kepada standar operasional (SPO) dan sejauh ini petugas juga sudah menunjukkan kinerja dan loyalitas yang baik.

\section{i. Sistem Pengawasan Alat Medis}


Pengawasan adalah kegiatan mengukur pelaksanaan dengan tujuan-tujuan menentukan sebab-sebab penyimpangan dan mengambil tindakan-tindakan korektif dimana perlu.

Menurut siagian (2011). Penciptaan sistem pengawasan sangat dibutuhkan dalam sebuah organisasi. Mengawasi berarti mengamati dan memantau dengan berbagai cara seperti pengamatan secara langsung kegiatan-kegiatan operasioanl dilapanga, membaca laporan dan berbagai cara lainnya, sementara berbagai kegiatan oeprasioanl dengan berlangsung.

Dalam hal pengawasan proses kegiatan pemeliharaan alat medis, Unit Teknik telah memiliki sistem pengawasan untuk memonitoring kegiatan tersebut, yang berdasarkan pada Program Kegiatan Pemeliharaan Alat Kesehatan. Adapun sistem pengawasan secara internal Unit Teknik dilakukan per tiga bulan sekali melalui laporan pelaksanaan kegiatan pemeliharaan per tiga bulan. Selain itu ada juga kegiatan pengawasan secara langsung oleh Kepala Unit Teknik. Kemudian untuk setiap tahunnya hasil dari laporan kegiatan pemeliharaan alat kesehatan secara menyeluruh dilaporkan ke pihak manajemen.

Menurut Muninjaya (2004) Semua aktivitas organisasi atau institusi diawasi, dipantau dan dibimbing agar aktivitas tetap berjalan sesuai tujuan dan target kinerja organisasi atau institusi (fungsi pengawasan dan pengendalian). Akhirnya dilakukan penilaian untuk menganalisis kinerja petugas dan organisasi. Penilaian meliputi masukan, proses dan transformasi atau konversi yaitu pelaksanaan fungsi-fungsi manajemen dan pelaksanaan program dan kegiatan organisasi atau institusi. Kemudian hasilnya dibandingkan dengan tujuan dan target kinerja organisasi atau institusi yang telah ditetapkan.

Berdasarkan hasil wawancara mendalam dengan informan, pengawasan terhadap kegiatan pemeliharaan alat medis di RSUD Arifin Achmad Pekanbaru tergolong cukup efektif, hal ini didasari pada sistem pengawasan yang berjenjang, mulai dari Pengawas yang bertugas mengawasi pelaksanaan kegiatan pemeliharaan alat medis. Hasil dari pelaksanaan tersebut dievaluasi oleh Kepala Unit Teknik per tiga bulan, kemudian setiap akhir tahun Kepala Unit Teknik bertanggung jawab untuk melaporkan kegiatan Unit Teknik secara umum, termasuk di dalamnya kegiatan pemeliharaan alat medis per tahun. Selain itu kegiatan pengawasan juga dilakukan oleh Kepala Unit Teknik secara langsung atau inpeksi ke lapangan pada waktu-waktu tertentu, melihat bagaimana pelaksanaan kegiatan pemeliharaan alat elektromedik terutama kegiatan perbaikan jika terjadi kerusakan alat (break down). 
Dapat disimpulkan bahwa sistem pengawasan kegiatan sudah baik, karena pengawasan dilihat dari laporan kegiatan, pelaksanaan jadwal kegiatan, pemeriksaan hasil, dan pemantauan langsung kondisi oleh operator pengguna alat secara berkala.

\section{j. Evaluasi Kegiatan Pemeliharaan Alat Medis}

Dalam menilai keseluruhan proses kegiatan pemeliharaan alat kesehatan termasuk alat eketromedik, Unit Teknik telah melakukan evaluasi baik terhadap realisasi pelaksanaan kegiatan pemeliharan dan perbaikan maupun mengenai kondisi alat medis. Evaluasi tersebut dilakukan secara internal Unit Teknik dan oleh pihak manajemen RS Arifin Achmad.

Berdasarkan wawancara dengan informan, didapatkan bahwa dirumah sakit Arifin Achamad sudah melakukan kelima proses manajeman dimana semua aktivitas manajerial dengan perencanaan dan berakhir pada evaluasi. Evaluasi internal Unit Teknik dilakukan setiap tiga bulan sekali melalui pemeriksaan hasil laporan realisasi kegiatan pemeliharaan dan perbaikan alat medis, serta realisasi kegiatan harian pemeliharaan alat medis. Sedangkan untuk evaluasi dari pihak manajemen RS Arifin Achmad dilakukan setiap akhir tahun, begitu juga dengan kegiatan kondisi kalibrasi alat dilakukan setiap satu tahun sekali. Sejauh ini hasil evaluasi yang telah dilakukan selalu diiringi dengan upaya perbaikan dan peningkatan serta digunakan oleh pihak rumah sakit sebagai bahan perencanaan kegiatan pemeliharaan alat medis kedepannya.

Berbeda dengan penelitian Pratiwi (2014) di rumah sakit banyumanik kota semarang, terkait kendala evaluasi pada proses pemeliharan alat kesehatan di Rumah Sakit Banyumanik baik dari input, proses dan output tidak termonitoring dari awal sehingga perencanaan yang dibuat Rumah Sakit tidak sesuai dengan program yang terlaksana sehingga hal tersebut dapat mengakibatkan rusaknya pelaksanaan program pemeliharaan yang semula berawal terencana menjadi tidak terencana.

Dalam hal pendokumentasian, sejauh ini Unit Teknik telah melakukan penyusunan laporan kegiatan pemeliharaan alat medis yang termuat didalam Laporan Unit Teknik secara keseluruhan. Kemudian untuk laporan mengenai kondisi alat secara internal rumah sakit dilakukan pembaharuan setiap kali pemeriksaan yang berkoordinasi dengan Unit Fasilitas Umum (Fasum) dan unit yang terkait. Kemudian hasil dari pemeriksaan tersebut dilampirkan dalam bentuk daftar inventaris sarana rumah sakit per ruangan, termasuk didalamnya alat medis.

Simpulan dari peneliti, sejauh ini sistem dokumentasi laporan hasil evaluasi sudah baik, terkait pelaksanaan atau realisasi kegiatan pemeliharaan alat medis 
berupa laporan kegitan pemeliharaan rutin, kegiatan perbaikan dan laporan kegiatan harian.

\section{KESIMPULAN}

Secara umum Sistem Pelaksanaan Manajemen Pemeliharaan Alat Medis Di Instalasi Pemeliharaan dan Perbaikan Peralatan Medis Rumah Sakit (IP3MRS) RSUD Arifin Achmad Provinsi Riau belum optimal:

1. Sumber Daya Manusia (SDM) dalam kegiatan pemeliharaan alat medis belum sesuai dengan Peraturan Menteri Kesehatan Dan Kepala Badan Kepegawaian Negara Nomor 28 Tahun 2013 Tentang Jabatan Fungsional Teknisi Elektromedis yang menyatakan dilingkungan rumah sakit umum tipe B untuk tenaga terampil 24 orang dan tenaga ahli 12 orang, sedangkan untuk rumah sakit Arifin Achmad Provinsi Riau saat ini berjumlah 8 orang dengan jumlah pertugas saat ini masih belum cukup memadai sehingga memerlukan pihak ke tiga dalam kegiatan pemeliharaan.

2. Ketersediaan dana pemeliharaan IP3MRS Rumah sakit umum daerah Arifin achmad secara umum sudah sesuai prosedur. Untuk proses realisasi anggaran juga tidak ada kendala. Hal tersebut dikarenakan pada saat proses pengajuan permintaan pencairan dana untuk kegiatan pemeliharaan melalui sistem request yang disertai dengan dasar permintaan yang diperoleh dari hasil laporan pemeriksaan.

3. Suku cadang atau bahan baku dalam pemeliharaan alat dirumah sakit umum daerah Arifin Achmad belum sepenuhnya terpenuhi hal ini dilihat dari segi kuatitas suku cadang dan bahan baku, sejauh ini Unit teknik sedikit mengalami kekurangan, hal tersebut diperkuat dengan ketepatan waktu pemeliharaan di tahun 2019 mengalami kendala untuk kecepatan waktu menanggapi kerusakan alat dari total 956 laporan kerusakan yang diterima oleh IP3MRS sebanyak 9 laporan yang ditanggapi lebih dari 15 menit, penyebab belum dapat dikerjakan karena pekerjaan perbaikan tersebut membutuhkan pihak ke $3(21 \%)$ ataupun sole agent .

4. Peralatan dan fasilitas dalam pemeliharaan, ada beberapa alat yang mungkin sekiranya dapat dipertimbangkan untuk dilakukan pengadaan peralatan agar lebih dapat menunjang kegiatan pemeliharaan secara lebih baik kedepannya ketersediaan fasilitas dan peralatan pemeliharaan alat medis belum memadai yang dilihat dari beberapa aspek yaitu terkait jumlah alat yang berada dirumah sakit dengan jumlah yang tidak sedikit yang harus dipelihara.

5. Kebijakan dan metode dalam pemeliharaan yang ada di IP3MRS rumah sakit umum daerah Arifin Achmad Pekanbaru Riau sudah berjalan dengan baik dan sesuai dengan standar prosedur oprasional (SPO) yang ada, kebijakan terkait pemeliharaan alat medis juga sudah disosialisasikan dengan baik kepada petugas pemeliharaan alat medis dan juga kepada operator pengguna alat medis.

6. Perencanaan pemeliharaan IP3MRS sejauh ini telah berjalan dengan baik, perencanaan tersebut dibuat pada setiap awal tahun, rencana tersebut tergabung ke dalam rencana kegiatan pemeliharaan alat kesehatan yang dilakukan berupa pembuatan jadwal kegiatan pemeliharaan Unit IP3MRS. 
7. Pengorganisasian dalam pemeliharaan alat medis sudah memiliki struktur organisasi yang langsung dikepalai oleh direktur rumah sakit, dan dibawahi oleh wakil direktur bidang pelayanan medis, untuk sistem komunikasi sudah terbilang efektif, dimana sistem komunikasi baik secara internal maupun ekternal sudah berjalan dengan baik guna mendukung keberlangsungan dalam pelaksanaan kegiatan pemeliharaan alat medis.

8. Pengawasan dalam pemeliharaan di RSUD Arifin Achmad Pekanbaru tergolong cukup efektif, dikarenakan pengawasan kegiatan pemeliharaan alat medis meliputi pemeriksaan laporan kegiatan pemeliharaan, pemeriksaan pelaksanaan jadwal kegiatan pemeliharaan, pemeriksaan hasil pemantauan langsung kondisi peralatan oleh operator pengguna alat secara berkala.

9. Pelaksanaan kegiatan pemeliharaan di RSUD Arifin Achmad sudah berjalan dengan baik, karena sudah melakukan kelima proses manajeman dimana semua aktivitas manajerial dengan perencanaan dan berakhir pada evaluasi yaitu dengan cara menelaah laporan kegiatan pemeliharaan, menelaah pelaksanaan jadwal kegiatan pemeliharaan, menelaah hasil pemantauan langsung kondisi peralatan oleh operator pengguna alat secara berkala.

\section{SARAN}

Berdasarkan simpulan yang didapat dalam penelitian maka untuk mengoptimalkan pelaksanaan Evaluasi Sistem Pelaksanaan Manajemen Pemeliharaan Alat Medis Di Instalasi Pemeliharaan Dan Perbaikan Peralatan Medis Rumah Sakit (IP3MRS) RSUD Arifin Achmad Provinsi Riau" dapat disarankan hal-hal sebagai berikut:

1. Disarankan dapat melakukan penambahan sumber daya manusia (SDM) di Rumah Sakit Umum Daerah Arifin Achmad dalam mengantisipasi resiko beban kerja pemeliharaan yang sifatnya diluar rencana, maka dibutuhkan sebuah analisis lebih lanjut mengenai beban kerja dan ketersediaan sumber daya manusia pemeliharaan alat medis. Hal ini dimaksudkan agar diketahuinya perbandingan antara beban kerja dengan jumlah petugas yang dibutuhkan. Selain itu dalam mengantisivasi resiko beban kerja pemeliharaan yang sifatnya diluar rencana, juga dapat dilakukan analisis kondisi alat elektromedik secara lebih spesifik, sehingga hasil dari analisis tersebut dapat dijadikan sebagai acuan dalam penentuan prioritas peralatan yang harus ditingkatkan upaya pemeliharaannya.

2. Disarankan terkait suku cadang atau bahan baku dalam pemeliharaan alat dirumah sakit umum daerah Arifin Achmad mengadakan atau membeli suku cadang baru dan bahan yang dibutuhkan agar alat yang rusak dapat lebih cepat ditangani oleh pihak Instalasi Pemeliharaan dan Perbaikan Peralatan Medis Rumah Sakit (IP3MRS).

3. Disarankan terkait Peralatan dan fasilitas pemeliharaan, perlunya pengadaan peralatan agar lebih dapat menunjang kegiatan pemeliharaan terkait fasilitas Gedung IP3MRS dan gudang penyimpanan suku cadang agar dapat dipisah. 
Pada kesempatan ini Peneliti mengucapkan terima kasih kepada Ketua STIKes Hang Tuah Pekanbaru, Ketua Program Studi Magister Kesehatan Masyarakat STIKes Hang Tuah Pekanbaru, Kepada Rumah Sakit Umum Daerah Arifin Achmad Pekanbaru Riau, terimakasih kepada Pembimbing Utama dan Pendamping, serta Penguji II dan Penguji III

\section{DAFTAR PUSTAKA}

Alamsyah, D. (2011). Manajemen Pelayanan Kesehatan. Jakarta: Nuha Medika

Azwar. (2009). Menjaga Mutu Pelayanan Kesehatan : Aplikasi Prinsip Untuk Pemecahan Masalah. Jakarta : Pustaka Sinar Harapan.

Ali Gunawan, Muhammad. (2015). Statistik Penelitian Bidang pendidikan, Psikologi dan Sosial. Yogyakarta

Creswell, John W. 2015. Penelitian Kualitatif dan Desain Riset: Memilih Diantara Lima Pendekatan. Yogyakarta: Pustaka Pelajar

Departemen Kesehatan Republik Indonesia. (2001). Pedoman penyelenggaran Instalasi Fasilitas Rumah Sakit. Jakarta.

Direktorat Bina Pelayanan Penunjang Medik dan Sarana Kesehatan Direktorat Jenderal Bina Upaya Kesehatan Kementerian Kesehatan RI. (2015). Pengelolaan Peralatan Kesehatan di Fasilitas Kesehatan. Kemenkes RI : Jakarta.

Djauhar, M. (2000). Manajemen Pemeliharaan Fasilitas Rumah Sakit untuk Direktur RS/Manajer Non Engineer dalam Seminar Manajemen Fasilitas RS dan Pemberdayaan IPS-RS. Jakarta : Direktorat Sarana dan Peralatan Medik Direktorat Jenderal Pelayanan Medik Departemen Kesehatan Republik Indonesia.

Departemen Kesehatan RI. Undang-Undang Republik Indonesia Nomor 36 Tahun 2009 Tentang Kesehatan. Jakarta: Kementrian Kesehatan RI: 2009

Departemen Kesehatan RI. Pedoman Pengujian dan Kalibrasi Alat Kesehatan. Jakarta : Departemen Kesehatan RI;2015

Departemen Kesehatan RI. Pedoman Penyelenggaraan Pelayanan rumah Sakit. Jakarta : Departemen Kesehatan RI;2001

Hamid, R. S., \& Ikbal, M. (2017). Pengaruh Physical Support Dan Contact Personel Terhadap Citra (Image) Pada Rumah Sakit Umum Daerah Andi Jemma Masamba Kabupaten Luwu Utara. Jurnal Manajemen, 3(1).

Kementerian Kesehatan Republik Indonesia. (2020). Klasifikasi dan Perizinan Rumah Sakit. Diakses 04 Juli 2020. 
Kementerian Kesehatan Republik Indonesia. (2014). Informasi Umum Rı ' - 'it. Diakses 05 Mei 2020.

Keputusan Menteri Pendayagunaan. Aparatur Negara Nomor: 41 /KEP/M.PAN/4/2003

Keputusan Menteri Kesehatan (Kepmenkes) No. 371/Menkes/SK/III/2007 Tentang Standar Profesi keteknisian elektromedis.

Laporan tahunan manajemen instalasi pemeliharaan dan perbaikan pemeliharaan peralatan medis rumah sakit (IP3MRS) RSUD AA tahun 2019.

Laporan tahunan Rumah Sakit Umum Daerah Arifin Achmad Pekanbaru Riau tahun 2019.

Miles, M. B. \& Huberman, M. (1992). Analisis Data Kualitatif. Jakarta: Penerbit Universitas Indonesia dalam emzir, 2010.

Menteri Kesehatan Indonesia dan Kepala Badan Kepegawaian Negara. Petunjuk Pelaksanaan Peraturan Menteri Pendayagunaan Aparatur Negara dan Reformasi Birokrasi Republik Indonesia Nomor 28 Tahun 2013 Tentang Jabatan Fungsional Teknisi Elektromedis dan Angka Kreditnya. Jakarta: Menteri Kesehatan Indonesia dan Kepala Badan Kepegawaian Negara; 2013

Manullang, 2008, Dasar-Dasar Manajemen, Yogyakarta: Ghalia Indonesia (Gl)

Peraturan Menteri Kesehatan No 363/Menkes/PER/IV/1998 tentang Pengujian dan Kalibrasi Alat Kesehatan pada sarana Pelayanan Kesehatan," kemenkes RI, 2015.

Pringgodani, S. (2013). Studi Tentang Pemeliharaan Bangunan Gedung Rumah Sakit Umum Daerah Harjono Kabupaten Ponorogo (Doctoral dissertation, UAJY).

Sabarguna, B.U. (2007). Sistem Informasi Pemeliharaan Alat Medis Rumah Sakit. Sagung Seto.

Saryono. (2010). Pedoman Praktis Manajemen Perawatan Mesin Industri. Bandung : PT. Refika Aditama.

Siagian, S, P. (2011). Manajemen Stratejik. Jakarta: PT Bumi Aksara.

Sudradjat, A. (2011). Pedoman Praktis Manajemen Perawatan Mesin Industri. Bandung: PT Refika Aditama.

Sulaeman, E. S. (2009). Manajemen Kesehatan-Teori dan Praktik di Puskesmas. Gajah Mada University Press: Yogyakarta.

Undang-Undang RI Nomor 44 Tahun 2009 tentang Rumah Sakit. Jakarta. 2009

Wijono, D. (2009). Manajemen Mutu Pelayanan Kesehatan. Surabaya : Airlangga University Press.

World Health Organization Regional Committee for the Eastern Mediterranean (WHO RCEM). (2010). The role of medical devices and equipment in contemporary health care systems and services http://www.emro.who.int. Diakses 06 Mei 2020. 